\title{
Human impact on large rivers: the influence of groynes of the River Oder on larval assemblages of caddisflies (Trichoptera)
}

\author{
Edyta Buczyńska $\cdot$ Agnieszka Szlauer-Lukaszewska $\cdot$ Stanisław Czachorowski • \\ Paweł Buczyński
}

Received: 17 June 2017/Revised: 28 April 2018/Accepted: 30 April 2018/Published online: 9 May 2018

(C) The Author(s) 2018

\begin{abstract}
The influence of groynes in large rivers on caddisflies has been poorly studied in the literature. Therefore, we carried out an investigation on the $420-\mathrm{km}$ stretch of the River Oder equipped with groynes. At 29 stations, we caught caddisflies in four habitats: current sites, groyne fields, riverine control sites without groynes and in the river's oxbows. We found that groyne construction increased species richness, diversity, evenness, and altered the structure of functional groups into more diversified and sustainable ones compared to the control sites. The groyne field fauna is similar to that of natural lentic habitats, but its composition is largely governed by the presence of potential colonists in the nearby oxbows. We distinguished three of the river's caddisfly
\end{abstract}

Handling editor: Zhengwen Liu

E. Buczyńska ( $\square)$

Department of Zoology, Animal Ecology and Wildlife Management, University of Life Sciences, Lublin, Poland e-mail: edyta.buczynska@gmail.com

\section{A. Szlauer-Łukaszewska}

Department of Invertebrate Zoology and Limnology,

Szczecin University, Szczecin, Poland

S. Czachorowski

Department of Ecology and Environmental Protection,

University of Warmia and Mazury, Olsztyn, Poland

P. Buczyński

Department of Zoology, Maria Curie-Skłodowska

University, Lublin, Poland assemblages. The distribution of Trichoptera was governed inter alia by the plant cover and the amount of detritus, and consequently, the food resources. Oxygen, nitrates, phosphates and electrolytic conductivity were important as well. Groynes have had positive effects for caddisflies-not only those in the river itself, but also those in its valley. They can therefore be of significance in river restoration (although originally they served other purposes), especially with respect to the radically transformed ecosystems of large rivers.

Keywords Trichoptera - Species assemblages ·

Large river · Groyne fields - Environmental

disturbances

\section{Introduction}

Large rivers are aquatic ecosystems that have been heavily modified by humans and over many centuries. Urbanisation, industry, chemical pollutants, land-use change, watercourse alterations, canalisation and dam construction (Malmqvist \& Rundle, 2002) limit biodiversity in rivers and their valleys, reduce water retention in river valleys and diminish their selfpurification capabilities (Coops et al., 2006; Tockner et al., 2009). Some human actions, however, may have unintentionally reversed the negative effects of regulation. They include the construction of groynes 


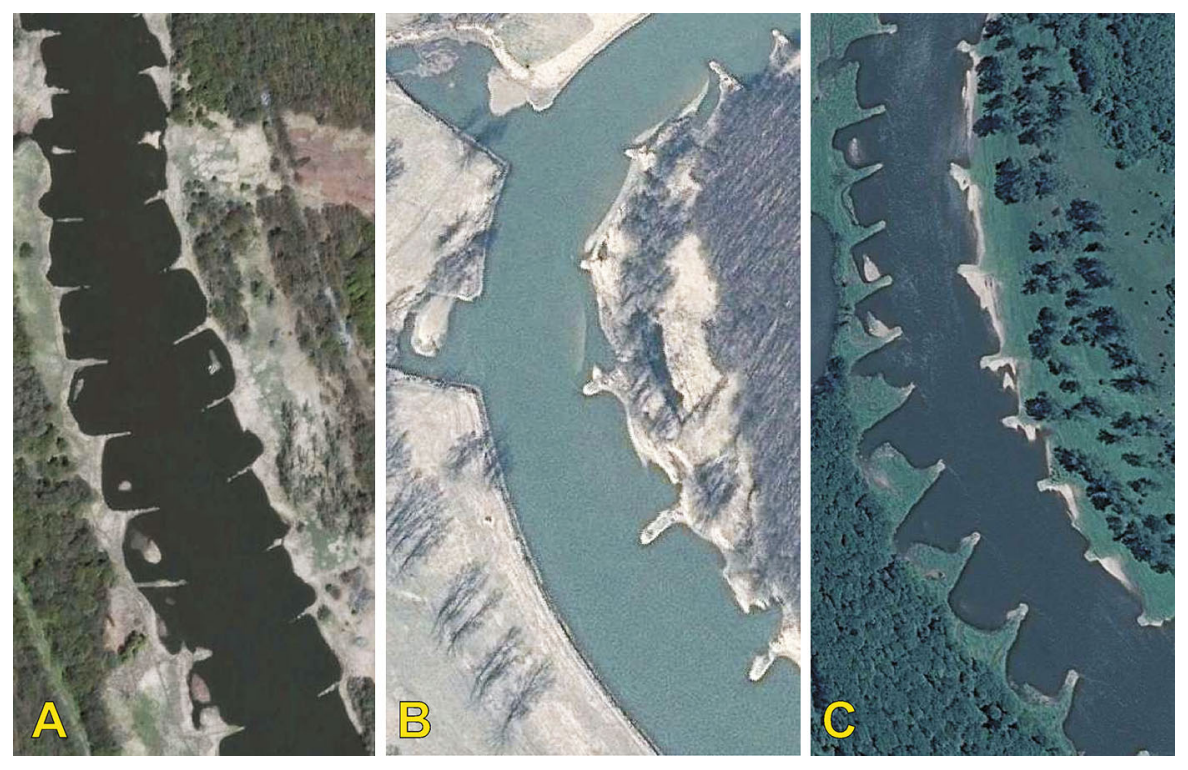

Fig. 1 Examples of groyne distribution in the Oder valley: A groynes of similar length on a straight stretch of the river; $\mathbf{B}$ irregularly shaped groynes along one of the river banks; C groynes of different lengths on both banks of a river bend (source: Google Earth maps)

(Fig. 1) which are hard hydraulic structures built at right angles to a river bank. They are made from a wide variety of materials: in recent years, rock and concrete have been most often used. The primary aim of these structures is to make the river channel narrower, interrupt sediment transport by trapping sediments between groynes and protect river banks from erosion. This, in turn, deepens the water in the channel, thereby prolonging the period for which the river is navigable. Structures of this kind have long been used in many countries. In Poland, groynes have been built on the Vistula (Wisła), Warta and Oder (Odra). The Oder, the object of our study, has the largest number of groynes: they were built at regular intervals over a very long distance (Rast et al., 2000), creating the largest uniform stretch of river in Poland (40\% of the river's length) with altered habitat conditions.

The waters between the groynes, known as 'groyne fields', are much calmer than those in the mainstream, and lentic habitats have regenerated there. The various stages of biological succession in the groyne fields encompass the accumulation of rock debris and detritus, the growth of submergent and emergent vegetation, and ultimately the appearance and stabilisation of assemblages of aquatic invertebrates and vertebrates. These approaches have been used in the restoration of original river ecosystems, in which the formation of various types of structures directing the water flow and the recreation of meanders are among the basic techniques for restoring the diversified horizontal river regime and its biodiversity (Żelazo \& Popek, 2002). Because of the increasing instream habitat complexity that positively affects the species richness and abundance of the macrofauna (e.g. Boyero, 2003; Mazão \& Conceição Bispo, 2016), we can expect successful colonisation of caddisfly species with lentic habitat preferences in the groyne fields. The potential sources of lentic species in a river valley are oxbows. Those of the Oder are not completely natural, since the points where they disembogue into the river are furnished with special groynes preventing their complete cutoff. This retards succession and prevents the disappearance of these water bodies, which can be treated as an unintended recompense for the reduction in standing water habitats. Since oxbows provide a potential species pool for lentic riverine habitats (Robinson et al., 2002; Sundermann et al., 2011), we have considered them in our project as comparative habitats for the groyne field fauna.

The presence of groynes has a positive influence, above all, on fish (e.g. Bischoff \& Wolter, 2001), and to a lesser extent on aquatic invertebrates (e.g. Barbosa et al., 2006; Nakano \& Nakamura, 2006; SzlauerŁukaszewska, 2015). However, there are still no data concerning the biological response of different taxonomic groups of organisms to varied river channel 
modifications (Horsák et al., 2009), and the biotic effects of river restoration on aquatic assemblages are still poorly understood (Sundermann et al., 2011).

This also applies to caddisflies: there are no comprehensive data on the influence of groynes on caddisfly assemblages, even though caddisflies are among the more important and numerous constituents of the river benthos, occupying the largest number of trophic and microhabitat niches of all aquatic invertebrates (Holzenthal et al., 2007). They are, moreover, good indicators of a river's ecological status (Cèrèghino et al., 2001) and of water quality (Pirvu \& Pacioglu, 2012). The latter aspect is particularly important in the case of the Oder: although its waters have been placed in biochemical and physical and chemical classes 2 or 3 (good or satisfactory quality), the overall quality of its waters is poor (class 4) resulting from their high nutrient levels (Lewicki, 2011; WIOŚ Wrocław, 2012). Identifying assemblages of Trichoptera, drivers of their distribution, assessing their response to transformations and disturbances, and understanding their habitat relationships in the ecosystems of large rivers may not only be recognisably important. Most importantly, the knowledge acquired can be applied to the implementation of EU recommendations for biodiversity conservation and improving the status of waters, contained in the Natura 2000 programme and the Framework Water Directive.

This study examines the following hypotheses: (1) the fauna and functional groups of Trichoptera resemble those of natural habitats of a similar character, (2) groyne constructions secondarily increase the biodiversity of the river and its valley by introducing habitat complexity, (3) both physical and chemical and structural (hydrodynamic) factors are key to the distribution of caddisfly species in a river subjected to human pressure.

\section{Materials and methods}

Study area

The Oder rises in the Oderské vrchy mountains (eastern Czech Republic) and empties into the Szczecin Lagoon, and ultimately the Baltic Sea (north-western Poland). With its length of $854 \mathrm{~km}$ and catchment area of $118861 \mathrm{~km}^{2}$, the Oder has the third-largest drainage basin and the sixth-greatest flow rate of all the rivers entering the Baltic Sea (Schöll et al., 2003).

The present study investigated the middle and lower reaches of the Oder over a distance of some $420 \mathrm{~km}$ (Fig. 2) from Uraz $\left(51^{\circ} 14^{\prime} \mathrm{N}, 16^{\circ} 51^{\prime} \mathrm{E}\right)$ to Ognica $\left(53^{\circ} 04^{\prime} \mathrm{N}, 14^{\circ} 22^{\prime} \mathrm{E}\right)$. Groynes were studied over a distance of $306 \mathrm{~km}$, from Ścinawa $\left(51^{\circ} 24^{\prime} \mathrm{N}\right.$, $\left.16^{\circ} 25^{\prime} \mathrm{E}\right)$ to Czelin $\left(52^{\circ} 44^{\prime} \mathrm{N}, 14^{\circ} 23^{\prime} \mathrm{E}\right)$; this is $40 \%$ of the Oder's total length.

Local hydro-engineering works on the Oder (weir construction) were undertaken as early as the thirteenth century, but the river was regulated on a large scale between 1741 and 1896. As a result, the Oder lost its meandering character, leaving many oxbows, now cut off from the mainstream. Around 10000 groynes were constructed to protect the river banks from erosion: this shifted the main current to the middle of the channel, which also improved conditions for navigation. The groynes are built of stone blocks, and their tips, which receive the full force of the faster flowing, turbulent waters, are bare. There is usually sand or gravel in the sediment. The sediments in the areas between the groynes, known as groyne fields, where the current is not so strong, are sandy or muddy, while those in the inner parts of the groyne fields are mostly muddy and support marshland vegetation with dominant Phalaris arundinacea; elodeids are found in this zone, too. The sediments in the middle, deepest part of the groyne fields are sandy, often with traces of deoxygenation; this is where big boulders and large amounts of shell debris accumulate. The habitat conditions in this area resemble those of the supralittoral.

Apart from the areas of standing water between the groynes, the other lentic habitats along the stretch of the Oder that we investigated are oxbows (length: 520-5000 m; width: 20-630 m). They are usually the remains of former meanders that were cut off as a result of the river's regulation. Their bottom sediments are sandy and silty with a substantial admixture of organic matter, sometimes forming a layer of sapropel. The littoral zone is dominated by sedges (Carex spp.) with admixtures of other helophytes. Elodeids and nympheids are also present. When water levels are high, the terrestrial vegetation by the shore is inundated. 


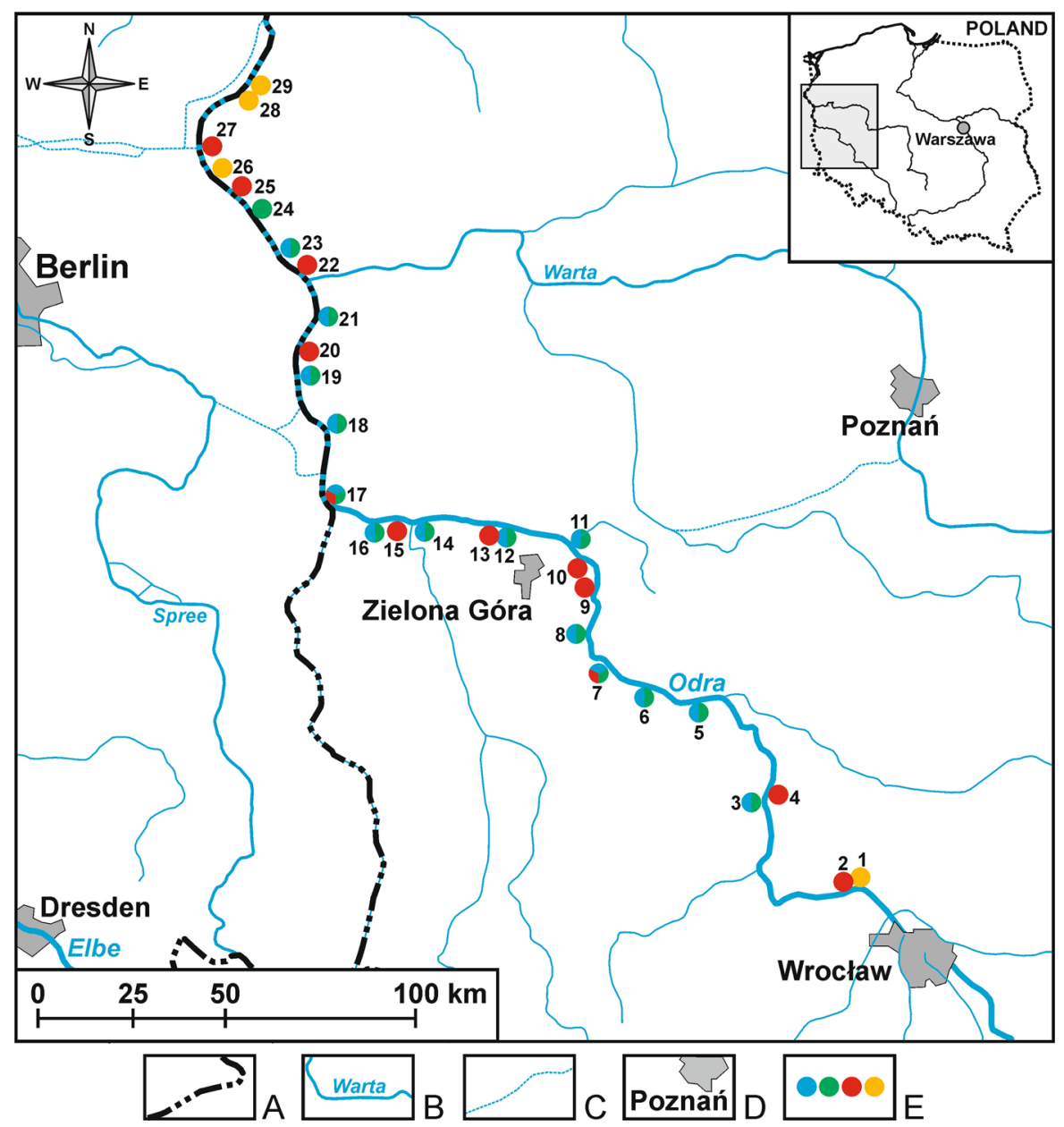

Fig. 2 Study area. A national boundary, B large rivers, C tributaries, D cities, E sampling stations (orange dots-control sites, green dots—-groyne fields, blue dots—current sites, red dots-oxbows)

Sampling methods

Sample materials were collected at 29 research stations (Fig. 2), whereas the groynes themselves were investigated at 15 of them (Sites: $3,5-8,11,12$, 14, 16-19, 21, 23, and 24). The groyne site samples were taken from the groyne tips ("current sites") at 13 stations and from the groyne fields at 14. For comparison, the fauna of oxbows as natural areas of standing water was analysed at 12 stations (Sites: 2, 4, $7,9,10,13,15,17,20,22,25$, and 27), while 4 stations (Sites: 1, 26, 28, and 29) were on stretches of the river without groynes but with reinforced banks ("control sites").

Samples of benthos (497 in all) were taken in the spring, summer and autumn of 2009 and 2010. The material was gathered by hand with a long-handled net ( $25 \mathrm{~cm}$ square frame, $50 \mu \mathrm{m}$ mesh). On an even bottom, the net was dragged for a set distance in order to gather up the surface layer of bottom sediments. Where the bottom was overgrown or uneven, stony or very hard, the sample was obtained by sweeping. The sampling sites were designated in such a way as to include all the microhabitats present at a given station and to ensure that they all differed distinctly from one another. In general, we collected 186 samples from sand, 238 from mud, 31 from gravel and 59 from rocks. 309 samples were gathered from the sites with plants and 188 from sites without vegetation.

The mud was rinsed out of the samples in the field in a $50 \mu \mathrm{m}$ net, while the larger debris was removed on a $5 \mathrm{~mm}$ mesh sieve (during this procedure 
macrobenthic organisms were picked out by hand). The mineral fractions were removed from sandy and gravelly sediments by sedimentation. The samples were then fractionated into macro- and meiobenthos on a $3 \mathrm{~mm}$ mesh net. The material was preserved in 98\% ethanol.

The caddisflies were identified to species level whenever possible. Identification to a higher taxon (genus or family) was necessary if younger larval stages were present in the material. Exceptions were larvae of the genus Hydroptila, all of which are impossible to identify to species level, and the genus Anabolia, the individuals of which were either $A$. furcata Brauer, 1857 or A. laevis (Zetterstedt, 1840).

The following parameters were measured at every station: the specific electrolytic conductivity of the water (cond), total dissolved solids (TDS), salinity (salin), $\mathrm{pH}(\mathrm{pH})$, dissolved oxygen concentration $\left(\mathrm{O}_{2}\right)$, temperature (temp)—all with a Hach-Lange HQ40d multi-parameter meter; transparency (trans) was estimated using a Secchi disc. Water samples were analysed on the sampling day with Slandi LF 300 portable photometers for the presence of contaminants and sewage. With this instrument, the following parameters were measured: ammonium nitrogen $\left(\mathrm{NH}_{4}\right)$, nitrites $\left(\mathrm{NO}_{2}\right)$, nitrates $\left(\mathrm{NO}_{3}\right)$, phosphates $\left(\mathrm{PO}_{4}\right)$ and water hardness (hard).

The following structural factors were determined at every station: water depth (depth), littoral width (lit_width), type of substrate (rocks, gravel, sand, detritus) and plant coverage (plants). The substrate composition was estimated visually as the proportion of each of the following substrate particle size classes: silt/clay/mud: ( $<0.06 \mathrm{~mm}$ diameter), sand (0.06-2), gravel (> 2-64) and rock (> 64) (Gordon et al., 1992). The vegetation was classified using Braun-Blanquet phytosociological records. Table 1 lists the relevant values (minimum, maximum, mean, standard deviation) of 19 environmental variables relating to the River Oder, which are examined in the following analysis.

\section{Data analysis}

The material was analysed with respect to species and ecological (functional) groups using the following indices: dominance, frequency, evenness-Buzas and Gibson's formula, faunistic similarities: quantitative-Jaccard's formula, quantitative - the Bray-
Curtis formula and Shannon's index. Hierarchical agglomerative clustering with the Unweighted Pair Group Method with Arithmetic Mean (UPGMA) of pooling species allowed us to distinguish caddisfly assemblages in the river based on qualitative similarity relationships. Non-metric multidimensional scaling (NMDS) revealed the relationships between the sites representing these four habitats based on BrayCurtis faunistic similarities. We also used NMDS (based on a taxa presence/absence matrix) to detect whether there was any potential environmental gradient impinging on the caddisfly faunas of the River Oder and its oxbows and similar riverine habitats in Europe: a regulated river-the Elbe (Scholz et al., 2005), two natural rivers - the Bug and its oxbows (Serafin, 2004), the Neman (Czachorowski, 2004), an artificial watercourse linked to the Oder-the OderSpree Canal (Müller et al., 2006), as well as the Odra 10 years ago (Schöll et al., 2003). NMDS and cluster analyses were performed in the PAST 3.15 program (Hammer et al., 2001).

Functional groups (FG) of caddisflies in relation to their current and trophic preferences are given after Graf et al. (2008), with some modifications taking into consideration the regional specifics of the caddisfly fauna. Taxa were allocated to four categories, according to their current speed preferences: limnobionts (lib) - species inhabiting standing waters only, limnophils (lip)—species usually inhabiting standing waters, rarely occurring in slowly flowing waters, limnorheophils (lrp)—species preferring standing waters but regularly occurring in slowly flowing ones, and rheophils (rlp) — species occurring in moderately to fast-flowing flowing waters. With regard to feeding strategies, six categories were distinguished: algaepiercers (alg-pie), filter feeder-predators (ff-pre), gatherers (gat), predators (pre), shredders (shr) and shredder-predators (shr-pre).

We used the Kruskal-Wallis test with Dunn's post hoc test to find significant differences between the densities and taxa richness of Trichoptera in the four habitats as well as in four substratum types. We applied the Mann-Whitney $U$ test to detect differences between the densities and taxa richness of caddisflies in sites with or without vegetation in the four habitats. All tests were carried out in the Statistica 10.0. program.

Multivariate ordination analyses were used to determine the environmental parameters responsible 
Table 1 Environmental variables (physical and chemical and structural) measured and estimated at the study sites on the River Oder

\begin{tabular}{|c|c|c|c|c|c|c|c|c|c|c|c|c|}
\hline & $\begin{array}{l}\mathrm{NH}_{4} \\
{[\mathrm{mg}} \\
\left.1^{-1}\right]\end{array}$ & $\begin{array}{l}\mathrm{NO}_{2} \\
{[\mathrm{mg}} \\
\left.1^{-1}\right]\end{array}$ & $\begin{array}{l}\mathrm{NO}_{3} \\
{[\mathrm{mg}} \\
\left.1^{-1}\right]\end{array}$ & $\begin{array}{l}\mathrm{O}_{2}[\mathrm{mg} \\
\left.1^{-1}\right]\end{array}$ & $\mathrm{pH}$ & $\begin{array}{l}\mathrm{PO}_{4} \\
{[\mathrm{mg}} \\
\left.1^{-1}\right]\end{array}$ & $\begin{array}{l}\text { Cond }[\mu \mathrm{S} \\
\left.\mathrm{cm}^{-1}\right]\end{array}$ & $\begin{array}{l}\text { TDS } \\
{[\mathrm{mg}} \\
\left.1^{-1}\right]\end{array}$ & $\begin{array}{l}\text { Temp } \\
{\left[{ }^{\circ} \mathrm{C}\right]}\end{array}$ & $\begin{array}{l}\text { Hardn } \\
{\left[\mathrm{mg} \mathrm{l}^{-1}\right]}\end{array}$ & $\begin{array}{l}\text { Trans } \\
{[\mathrm{m}]}\end{array}$ & $\begin{array}{l}\text { Salin } \\
{[\% 0]}\end{array}$ \\
\hline \multicolumn{13}{|c|}{ Physical and chemical parameters of water } \\
\hline Min & 0.1 & 0.009 & 0.6 & 5.78 & 6.74 & 0.009 & 520 & 227 & 6.7 & 8.38 & 0.5 & 0.28 \\
\hline Max & 0.7 & 0.123 & 10.36 & 14.67 & 9.06 & 0.98 & 1540 & 771 & 22.8 & 16.14 & 1.5 & 0.78 \\
\hline SD & 0.1070 & 0.0222 & 2.1136 & 1.7059 & 0.5943 & 0.1491 & 207.70 & 100.47 & 4.3536 & 1.6937 & 0.2348 & 0.1049 \\
\hline \multirow[t]{2}{*}{ Mean } & 0.26 & 0.03 & 6.27 & 11.00 & 8.27 & 0.15 & 897.56 & 434.12 & 14.53 & 12.46 & 0.92 & 0.44 \\
\hline & \multicolumn{2}{|c|}{ Depth [m] } & \multicolumn{3}{|c|}{ Lit_width [m] } & Rocks & \multicolumn{2}{|l|}{ Gravel } & Sand & \multicolumn{2}{|c|}{ Detritus } & Plants \\
\hline \multicolumn{13}{|c|}{ Structural factors } \\
\hline Min & \multicolumn{2}{|c|}{0.05} & \multicolumn{2}{|l|}{1} & \multicolumn{2}{|r|}{0} & 0 & \multicolumn{2}{|c|}{0} & \multicolumn{2}{|l|}{0} & 0 \\
\hline Max & \multicolumn{2}{|c|}{2} & \multicolumn{2}{|l|}{4} & \multicolumn{2}{|r|}{5} & 5 & \multicolumn{2}{|c|}{5} & \multicolumn{2}{|l|}{5} & 5 \\
\hline SD & \multicolumn{2}{|c|}{0.4366} & \multicolumn{2}{|c|}{0.8308} & & 1.1996 & \multicolumn{2}{|l|}{1.0606} & 1.5536 & \multicolumn{2}{|l|}{1.6004} & 1.3114 \\
\hline Mean & \multicolumn{2}{|c|}{0.54} & \multicolumn{2}{|c|}{2.23} & & 3.42 & \multicolumn{2}{|l|}{4.37} & 3.38 & \multicolumn{2}{|l|}{3.70} & 3.68 \\
\hline
\end{tabular}

The designations of the variables are explained in the text

Min minimum value, Max maximum value, SD standard deviations

for the distribution of caddisfly species in the Oder. Detrended Correspondence Analysis (DCA) was used first to detect the gradient length and, since the gradient was short $(<3 \mathrm{SD})$, the linear methodRedundancy Analysis (RDA) —was applied. Two separate analyses were applied to each group of environmental factors (Table 1). To test the significance of the variables $(P<0.05)$, the forward selection procedure was used with the Monte Carlo permutation test. RDAs were carried out in CANOCO 4.5 for Windows (ter Braak \& Šmilauer, 2002).

\section{Results}

A total of 497 hydrobiological samples were collected; caddisflies were present in 212 (42.6\%) of them. 1033 specimens of Trichoptera representing 45 taxa (33 species) were collected in general (Table 2). Most were found in the oxbows, with less than half as many in the groyne fields. The control sites yielded fewer still, while the smallest number were from the current. The overall density was also the highest in the oxbows, somewhat less in the groyne fields; it was 5 times less at the control sites than in the oxbows and 7 times less in the current. The taxonomic richness of the oxbows and groyne fields was identical with 31 taxa each; 12 taxa were from the control sites and 7 from the current
(Table 2). The Kruskal-Wallis test showed that the differences between densities $(P=0.068)$ and taxonomic richness $(P=0.45)$ of these habitats were not statistically significant.

The following taxa were the most frequent across the datasets: Anabolia sp. (21 sites), Hydropsyche guttata Pictet, 1834 (17 sites), Limnephilus flavicornis (Fabricius, 1787; 15 sites), young larval stages of Limnephilidae and the genus Limnephilus (14 each) and Oecetis (13). As many as 18 taxa were found at only one site. The dominance structure of the entire fauna (Table 2) was very uneven: two taxa were eudominant (Anabolia sp. and early instar Limnephilidae), another two were dominant (early instar Limnephilus sp. and Limnephilus flavicornis), seven were subdominant, while as many as 34 were recedent. The quantitative taxonomic structures in the various habitats differed. The genus Hydropsyche was the most numerous in the current, making up almost $90 \%$ of all taxa there. The groyne fields were dominated by larvae of the genus Anabolia and of Leptocerus tineiformis Curtis, 1834; the abundance of as many as 25 taxa was less than 5\% there. Dominating the oxbows were juveniles of Limnephilidae and the genus Anabolia; as in the groyne fields, there was a high number (26) of species with an abundance of less than $5 \%$. At the control sites larvae of the genera Anabolia and Limnephilus were the most numerous. Few taxa 
Table 2 Caddisflies of the River Oder and its oxbows

\begin{tabular}{|c|c|c|c|c|c|c|c|c|c|c|}
\hline \multicolumn{2}{|c|}{ Taxon } & \multirow{2}{*}{$\frac{\text { Codes }}{\text { Agr_sex }}$} & \multirow{2}{*}{$\frac{\text { Stations }}{7}$} & \multirow{2}{*}{$\begin{array}{c}\mathrm{C} \\
-\end{array}$} & \multirow{2}{*}{$\begin{array}{c}\mathrm{Cu} \\
-\end{array}$} & \multirow{2}{*}{$\begin{array}{l}\mathrm{G} \\
-\end{array}$} & \multirow{2}{*}{$\frac{\mathrm{O}}{0.19}$} & \multirow{2}{*}{$\frac{\mathrm{D}}{0.1}$} & \multirow{2}{*}{$\frac{F}{3.45}$} & \multirow{2}{*}{$\frac{\text { DEN }}{4}$} \\
\hline 1. & $\begin{array}{l}\text { Agraylea sexmaculata } \\
\text { Curtis, } 1834\end{array}$ & & & & & & & & & \\
\hline & Anabolia sp. & Ana_sp & $7-12,14-18,20-21,24-29$ & 65.19 & 3.95 & 28.86 & 15.65 & 25.07 & 65.52 & 5.8 \\
\hline \multirow[t]{3}{*}{2.} & $\begin{array}{l}\text { Athripsodes aterrimus } \\
\text { (Stephens, 1836) }\end{array}$ & Ath_ate & 22,27 & - & - & - & 1.15 & 0.58 & 6.9 & 4.5 \\
\hline & Athripsodes sp. & & 15,22 & - & - & - & 1.72 & 0.87 & 6.9 & 13.3 \\
\hline & Ceraclea sp. & Cer_sp & 5 & - & - & 1.34 & - & 0.39 & 3.45 & 16 \\
\hline 3. & $\begin{array}{l}\text { Cyrnus crenaticornis } \\
\text { (Kolenati, 1859) }\end{array}$ & Cyr_cre & $15,17,20,25,27$ & - & - & 2.35 & 0.95 & 1.16 & 17.24 & 6.1 \\
\hline \multirow[t]{2}{*}{4.} & $\begin{array}{l}\text { Cyrnus flavidus McLachlan, } \\
1864\end{array}$ & Cyr_fla & $11,17,18,20$ & - & - & 2.35 & 0.19 & 0.77 & 13.79 & 7.94 \\
\hline & Cyrnus sp. & & 12 & - & - & 0.34 & 0 & 0.1 & 3.45 & 1.1 \\
\hline 5. & $\begin{array}{l}\text { Ecnomus tenellus Rambur, } \\
1842\end{array}$ & Ecn_ten & 21 & - & - & 0.34 & 0 & 0.1 & 3.45 & 1.3 \\
\hline 6. & $\begin{array}{l}\text { Glyphotaelius pellucidus } \\
\text { Retzius, } 1783\end{array}$ & Gly_pel & $17,19,22,27$ & - & - & 0.34 & 0.95 & 0.58 & 13.79 & 2.75 \\
\hline 7. & $\begin{array}{l}\text { Grammotaulius } \\
\text { nigropunctatus (Retzius, } \\
\text { 1783) }\end{array}$ & Gra_nig & 9 & - & - & - & 0.19 & 0.1 & 3.45 & 2 \\
\hline \multirow[t]{2}{*}{8.} & $\begin{array}{l}\text { Halesus digitatus (Schrank, } \\
\text { 1781) }\end{array}$ & Hal_dig & 16 & 0.74 & - & 0.34 & - & 0.19 & 3.45 & 1.35 \\
\hline & Halesus sp. & & 16 & - & - & 0.34 & - & 0.1 & 3.45 & 0.8 \\
\hline 9. & $\begin{array}{l}\text { Hydropsyche } \\
\text { bulgaromanorum Malicky, } \\
1977\end{array}$ & Hyd_bul & $3,6-9,14,16$ & - & 21.05 & 7.72 & 1.15 & 4.36 & 24.14 & 5.3 \\
\hline 10. & $\begin{array}{l}\text { Hydropsyche guttata Pictet, } \\
1834\end{array}$ & Hyd_gut & $\begin{array}{l}5,6,8,9,11,12,14 \\
16-19,21,23,24,26\end{array}$ & 6.67 & 25 & 4.03 & 0.19 & 3.97 & 51.72 & 2.7 \\
\hline \multirow[t]{3}{*}{11.} & $\begin{array}{l}\text { Hydropsyche ornatula } \\
\text { McLachlan, } 1878\end{array}$ & Hyd_orn & 9 & - & - & - & 0.19 & 0.1 & 3.45 & 2 \\
\hline & Hydropsyche sp. & & $\begin{array}{l}6,8,11,12,14,16,17,19 \\
23\end{array}$ & - & 43.42 & 3.02 & - & 4.07 & 31.03 & 9.0 \\
\hline & Hydroptila sp. & & $5-8$ & - & 3.95 & 3.69 & - & 1.36 & 13.79 & 3.1 \\
\hline 12. & $\begin{array}{l}\text { Ironoquia dubia (Stephens, } \\
\text { 1837) }\end{array}$ & Iro_dub & 7 & - & - & 0.34 & - & 0.1 & 3.45 & 2 \\
\hline \multirow[t]{2}{*}{13.} & $\begin{array}{l}\text { Leptocerus tineiformis } \\
\text { Curtis, } 1834\end{array}$ & Lep_tin & $10,12,14,17,23,26,27$ & 1.48 & - & 13.76 & 0.76 & 4.55 & 24.14 & 25.5 \\
\hline & Leptoceridae & & $9,10,13,15,20,23,26,27$ & 0.74 & - & 0.34 & 1.34 & 0.87 & 27.59 & 2.3 \\
\hline 14. & $\begin{array}{l}\text { Limnephilus affinis Curtis, } \\
\quad 1834\end{array}$ & Lim_aff & $13,16,19,21-23,26-28$ & 2.22 & 1.32 & 6.04 & 3.63 & 3.97 & 31.03 & 6.8 \\
\hline 15. & $\begin{array}{l}\text { Limnephilus auricula } \text { Curtis, } \\
1834\end{array}$ & Lim_aur & 27 & - & - & - & 0.38 & 0.19 & 3.45 & 2.1 \\
\hline 16. & $\begin{array}{l}\text { Limnephilus binotatus } \\
\text { Curtis, } 1834\end{array}$ & Lim_bin & 22 & - & - & - & 0.57 & 0.29 & 3.45 & 3.35 \\
\hline 17. & $\begin{array}{l}\text { Limnephilus decipiens } \\
\text { (Kolenati, 1848) }\end{array}$ & Lim_dec & $9,11,16,21,22$ & - & - & 1.01 & 0.38 & 0.48 & 17.24 & 2.2 \\
\hline 18. & $\begin{array}{l}\text { Limnephilus flavicornis } \\
\text { (Fabricius, 1787) }\end{array}$ & Lim_fla & $\begin{array}{l}2,4,10,11,13,15-18,21 \\
\quad 22,25-27\end{array}$ & 0.74 & - & 6.04 & 8.21 & 6 & 48.28 & 8.7 \\
\hline 19. & $\begin{array}{l}\text { Limnephilus fuscicornis } \\
\text { Rambur, } 1842\end{array}$ & Lim_fuc & 29 & 2.22 & - & - & - & 0.29 & 3.45 & 1.15 \\
\hline
\end{tabular}


Table 2 continued

\begin{tabular}{|c|c|c|c|c|c|c|c|c|c|c|}
\hline \multicolumn{2}{|c|}{ Taxon } & \multirow{2}{*}{$\begin{array}{l}\text { Codes } \\
\text { Lim_fun }\end{array}$} & \multirow{2}{*}{$\begin{array}{l}\text { Stations } \\
21-22\end{array}$} & \multirow{2}{*}{$\frac{\mathrm{C}}{-}$} & \multirow{2}{*}{$\frac{\mathrm{Cu}}{-}$} & \multirow{2}{*}{$\frac{G}{0.34}$} & \multirow{2}{*}{$\frac{\mathrm{O}}{0.19}$} & \multirow{2}{*}{$\frac{\mathrm{D}}{0.19}$} & \multirow{2}{*}{$\frac{F}{6.9}$} & \multirow{2}{*}{$\frac{D E N}{4.65}$} \\
\hline 20. & $\begin{array}{l}\text { Limnephilus fuscinervis } \\
\text { (Zetterstedt, 1840) }\end{array}$ & & & & & & & & & \\
\hline 21. & $\begin{array}{l}\text { Limnephilus lunatus Curtis, } \\
1834\end{array}$ & Lim_lun & 11,16 & - & - & 1.01 & - & 0.29 & 6.9 & 2 \\
\hline 22. & $\begin{array}{l}\text { Limnephilus marmoratus } \\
\text { Curtis, } 1834\end{array}$ & Lim_mar & 22 & - & - & - & 0.95 & 0.48 & 3.45 & 40 \\
\hline 23. & $\begin{array}{l}\text { Limnephilus nigriceps } \\
\text { (Zetterstedt, 1840) }\end{array}$ & Lim_nig & 29 & 0.74 & - & - & - & 0.1 & 3.45 & 0.7 \\
\hline 24. & $\begin{array}{c}\text { Limnephilus politus } \\
\text { McLachlan, } 1865\end{array}$ & Lim_pol & 22 & - & - & - & 0.76 & 0.39 & 3.45 & 6.65 \\
\hline 25. & $\begin{array}{l}\text { Limnephilus rhombicus } \\
\text { (Linnaeus, 1758) }\end{array}$ & Lim_rho & 11 & - & 1.32 & - & - & 0.1 & 3.45 & 12 \\
\hline 26. & $\begin{array}{l}\text { Limnephilus stigma Curtis, } \\
1834\end{array}$ & Lim_sti & 22 & - & - & - & 0.19 & 0.1 & 3.45 & 2.7 \\
\hline \multirow[t]{3}{*}{27.} & $\begin{array}{l}\text { Limnephilus vittatus } \\
\text { (Fabricius, 1798) }\end{array}$ & Lim_vit & 25 & - & - & - & 0.19 & 0.1 & 3.45 & 2.9 \\
\hline & Limnephilus sp. & & $\begin{array}{l}10,13,14,16,17,20-27 \\
29\end{array}$ & 11.11 & - & 2.35 & 10.69 & 7.55 & 48.28 & 15.1 \\
\hline & Limnephilidae & & $8-10,13,16,17,20-27$ & 7.41 & - & 5.37 & 36.07 & 20.81 & 48.28 & 23.2 \\
\hline \multirow[t]{2}{*}{28.} & $\begin{array}{r}\text { Mystacides azurea } \\
\text { (Linnaeus, 1758) }\end{array}$ & Mys_azu & 8 & - & - & 0.34 & - & 0.1 & 3.45 & 4 \\
\hline & Mystacides sp. & & $9,17,25$ & - & - & 0.34 & 3.24 & 1.74 & 13.79 & 4.6 \\
\hline 29. & $\begin{array}{l}\text { Oecetis furva (Rambur, } \\
\text { 1842) }\end{array}$ & Oec_fur & 17,27 & - & - & 0.34 & 0.19 & 0.19 & 6.9 & 8.15 \\
\hline 30. & $\begin{array}{l}\text { Oecetis lacustris (Pictet, } \\
1834 \text { ) }\end{array}$ & Oec_lac & $2,11,15,17,18,21,25$ & - & - & 2.35 & 2.67 & 2.03 & 24.14 & 7.2 \\
\hline 31. & $\begin{array}{l}\text { Oecetis ochracea (Curtis, } \\
\text { 1825) }\end{array}$ & Oec_och & $1,2,11,15,18,24$ & 0.74 & - & 1.01 & 0.57 & 0.68 & 20.69 & 13.45 \\
\hline \multirow[t]{2}{*}{32.} & $\begin{array}{l}\text { Oecetis testacea (Curtis, } \\
1834 \text { ) }\end{array}$ & Oec_tes & 8,16 & - & - & 0.67 & - & 0.19 & 6.9 & 5.85 \\
\hline & Oecetis sp. & & $\begin{array}{l}2,6,9,10,12,15,17 \\
21-25,27\end{array}$ & - & - & 2.35 & 6.11 & 3.78 & 44.83 & 12.2 \\
\hline & $\begin{array}{l}\text { Triaenodes bicolor (Curtis, } \\
\text { 1834) }\end{array}$ & Tri_bic & $16,17,21,22$ & - & - & 1.01 & 0.38 & 0.48 & 13.79 & 2.68 \\
\hline \multicolumn{4}{|c|}{ Number of taxa } & 12 & 7 & 31 & 31 & & & \\
\hline \multicolumn{4}{|c|}{ Number of species } & 8 & 4 & 20 & 24 & & & \\
\hline \multicolumn{4}{|c|}{ Number of specimens } & 135 & 76 & 298 & 524 & & & \\
\hline \multicolumn{4}{|c|}{ Mean densities } & 11 & 7.3 & 9.6 & 9.4 & & & \\
\hline \multicolumn{4}{|c|}{ Shannon diversity index } & 1.31 & 1.4 & 2.61 & 2.26 & & & \\
\hline \multicolumn{4}{|c|}{ Eveness index } & 0.30 & 0.58 & 0.43 & 0.31 & & & \\
\hline
\end{tabular}

$\mathrm{C}$ control sites, $\mathrm{Cu}$ current sites (groyne tips), G groyne fields, $\mathrm{O}$ oxbows, D dominance, $\mathrm{F}$ frequency, DEN densities (indiv./m²)

occurred in all four habitat types: larvae of Anabolia sp., Hydropsyche guttata and Limnephilus affinis Curtis, 1834.
The quantitative faunistic associations between the various sites, classified according to habitat type, are given in the NMDS plot in Fig. 3. The fauna of the 
Fig. 3 Two-dimensional non-metric multidimensional scaling (NMDS) plot showing the arrangement of the study sites representing four habitat types based on BrayCurtis faunistic similarities (orange dots-control sites, green dots-groyne fields, blue dots-current sites, red dots-oxbows)

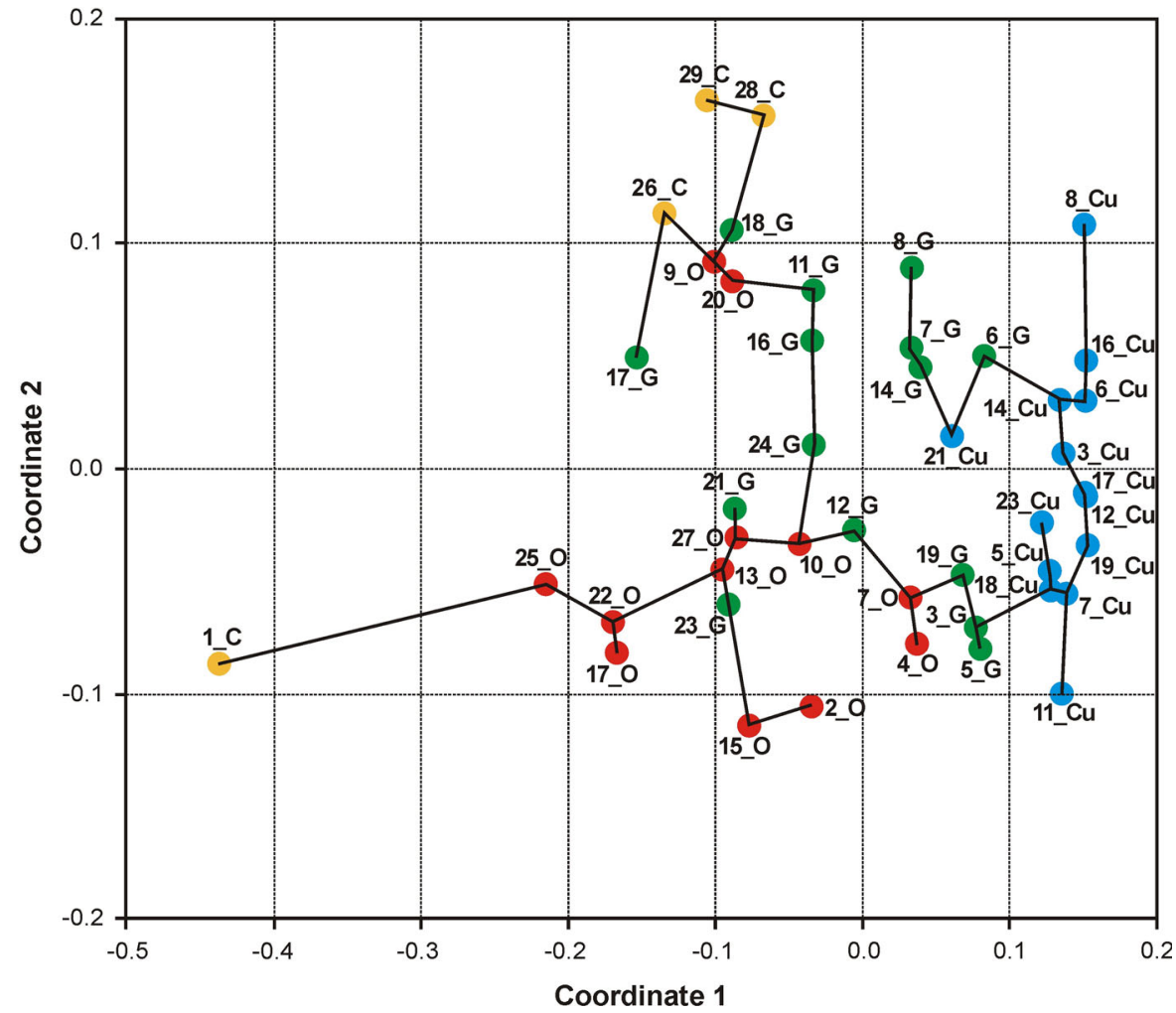

current sites is the most homogeneous and different from most sites. The groyne fields exhibit the greatest overlap with the oxbow fauna. Three of the control sites $(26,28$, and 29) share a similar fauna, being the least closely associated with the current. Worth emphasising is the fact that the most oxbow or groyne field sites are situated on opposite sides of Coordinate 2 , which indicates some differences between these habitat types. Spatial proximity (e.g. Sites 3, 4, and 5) may be responsible to some extent for the faunistic similarities found between groyne fields and oxbows. In general, the oxbows and groyne fields exhibited the greatest qualitative faunistic similarity (48\%), whereas the groyne fields and control sites were quantitatively the most similar (56\%). The caddisfly fauna at current sites displayed the greatest dissimilarity, the level of its similarity with the other three habitat types being very low.

Analysis of functional groups (FG) with respect to current preferences (Fig. 4a) showed that the proportions of species representing the various categories displayed the greatest similarity in the case of groyne fields and oxbows: limnophils and limnobionts were dominant in both habitats. The absolutely largest numbers of rheophils were found at the current sites, whereas limnophils were dominant at the control sites. The percentage abundances of limnobionts, limnophils and rheophils were roughly the same in the river itself, but limnophils predominated across the dataset (river and oxbows). The feeding group structure in the four habitats (Fig. 4b) was highly diversified: the control and current sites featured the lowest number of trophic categories and the overwhelming dominance of one of them: shredder-predators in the former and filter feeding predators in the latter. The species found in the groyne fields and oxbows were representative of all the feeding groups, but shredder-predators were dominant $-51 \%$ in the groyne fields and as many as $76 \%$ in the oxbows. Indeed, more than half of all the river caddisflies were shredder-predators.

Analysis of species co-occurrence in the dataset from the river itself (Fig. 5) yielded three distinct assemblages of Trichoptera. Assemblage 1 contained species with a preference for lentic habitats: they were almost exclusively large detritus feeding/predatory Limnephilidae. This assemblage could be regarded as typical of groyne fields, so long as the appropriate aquatic vegetation was present. Assemblage 2 
Fig. 4 Percentage contribution of trichopteran functional groups based on a current preferences (liblimnobionts, liplimnophils, lrplimnorheophils, rhprheophils) and $\mathrm{b}$ food preferences (alg-piealgae-piercers, ff-pre-filter feeder-predators, gatgatherers, pre-predators, shr-shredders, shr-preshredder-predators) in each habitat $(\mathrm{C}, \mathrm{Cu}, \mathrm{G}, \mathrm{O})$, in the River Oder (R) and at all the stations (T) (a)

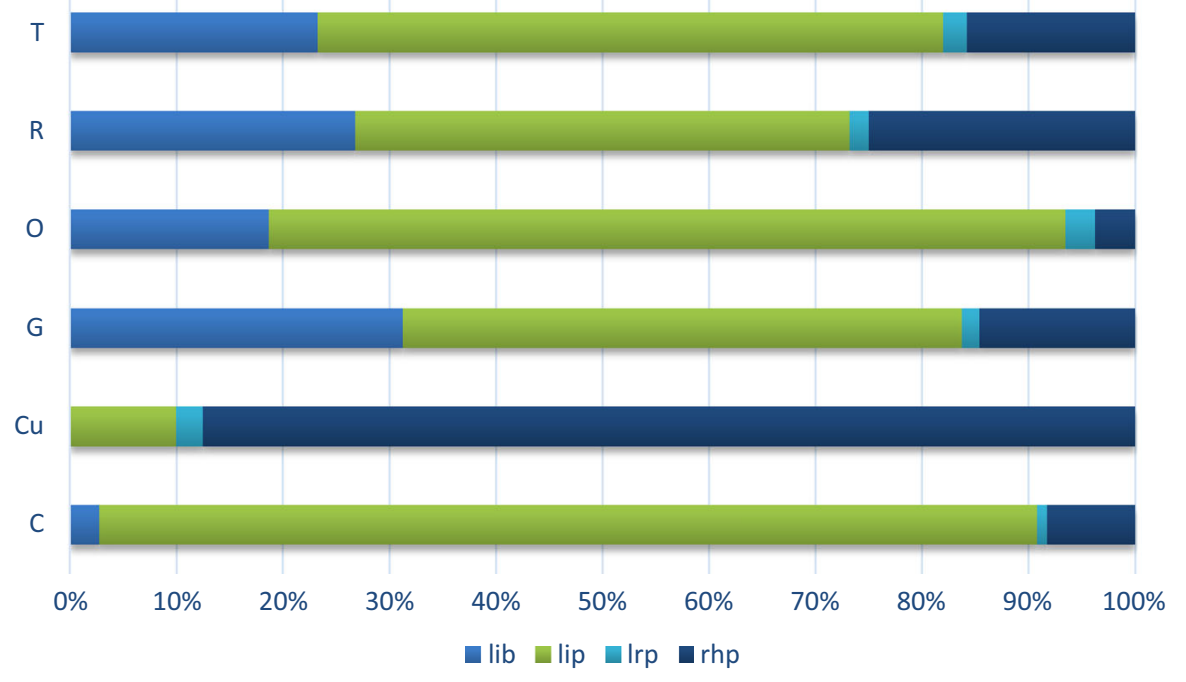

(b)

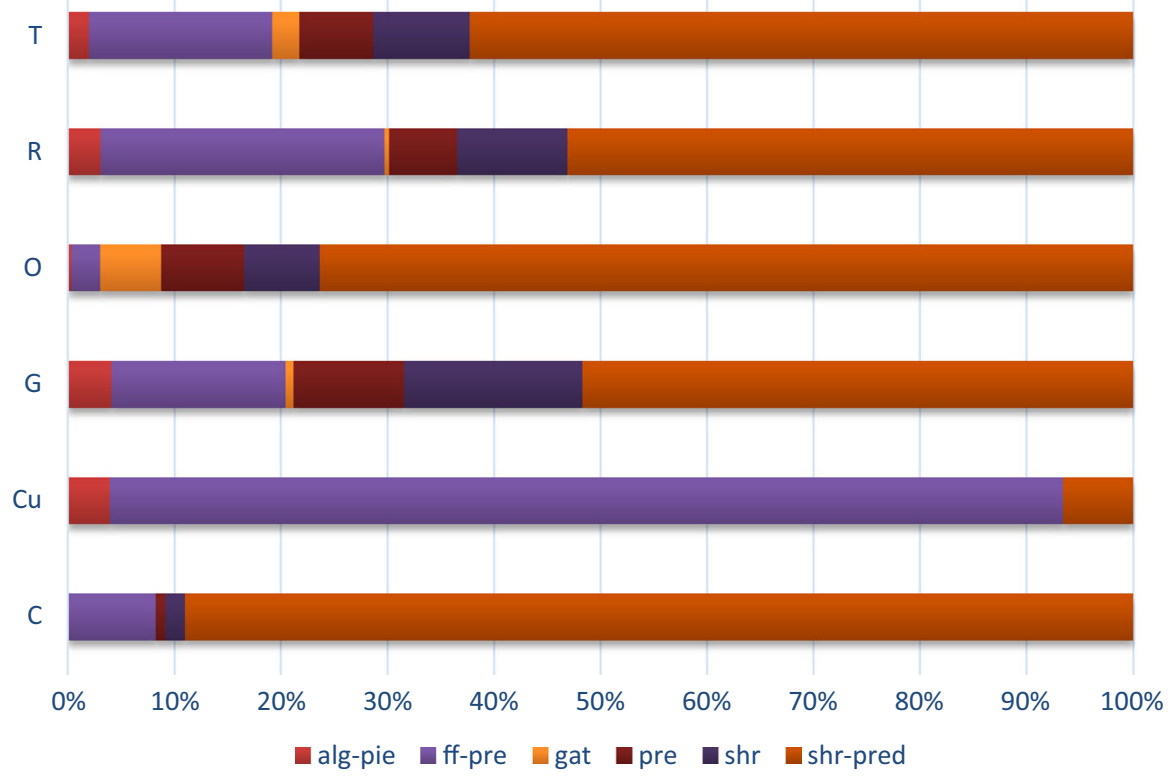

consisted of two separate but equivalent subgroups: one included two species from the genus Hydropsyche, which could be treated as indicators for the groyne tips, while the other encompassed limnophilic Anabolia larvae and Limnephilus flavicornis, which inhabited groyne fields and oxbows to an equal extent. The character of assemblage 2 was transitional between current-groyne fields and oxbows. Assemblage 3 comprised limnobionts, mainly predaceous caddisflies from the families Leptoceridae and Polycentropodidae. This assemblage could also be regarded as an indicator for groyne fields, although its constituent species have never been found at the groyne tips. The species in assemblages 1 and 3, characteristic of groyne fields, were also found in oxbows in a ratio of 2:1.

Separate redundancy analysis (RDA) of the influence of two sets of environmental variables (physical and chemical as well as structural) relating to the river showed that these factors explained to only a small degree the overall variability of the river's caddisflies (15.5 and 9\%, respectively). In the first analysis 


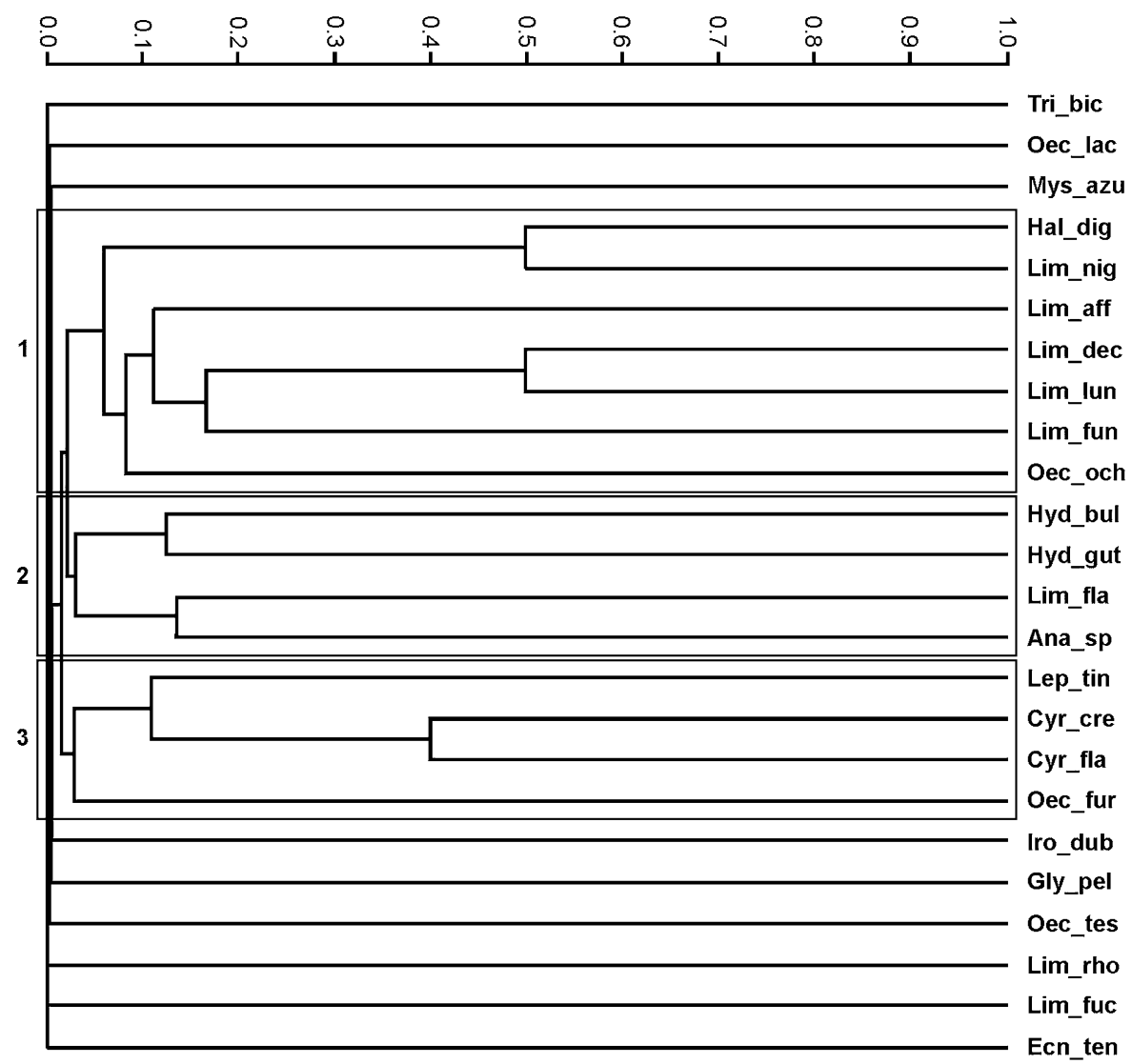

Fig. 5 Cladogram showing the caddisfly assemblages of the River Oder based on species co-occurrences (Jaccard's formula). The taxon codes are given in Table 1

(Fig. 6a), the first axis of the plot was defined by the temperature and the second by the oxygen content. The following of the 12 variables were statistically significant-in descending order: oxygen content, nitrates, electrolytic conductivity and phosphates. As regards membership of the caddisfly assemblages, only two of the seven structural parameters of the study sites (Fig. 6b) were significant: detritus on mud and plant coverage. The first axis defined the former parameter, and the second axis the latter. The situation regarding the substrate is less clear: the vector of the detritus fraction on mud lies close to the gravel substrate, a non-significant factor, which hinders an unequivocal interpretation of the results.

Comparison of the species composition of the Oder and its oxbows with different river systems (both natural and anthropogenically disturbed) as well as a canal in Europe and the Oder itself 10 years ago (Fig. 7) reveals some trends. The fauna of the Oder and its oxbows is the most similar to the fauna of the
River Bug oxbows. On the NMDS plot these three habitats are combined with rivers of a natural character: the Bug and the Neman. The fauna of the Oder 10 years ago most resembles the fauna of the Elbe, while the most distinct fauna is that of the Oder-Spree Canal. These three latter habitats are in opposition to the remaining habitats against coordinate 2, which indicates that this dimension may be associated with the degree of habitat transformation.

\section{Discussion}

The effects of groynes on the caddisfly fauna of a river and its valley

According to Barbosa et al. (2006), hydro-engineering works interfere with the natural continuity of the river, making it more homogeneous. Groynes were constructed along the Oder, a river already radically 
(a)

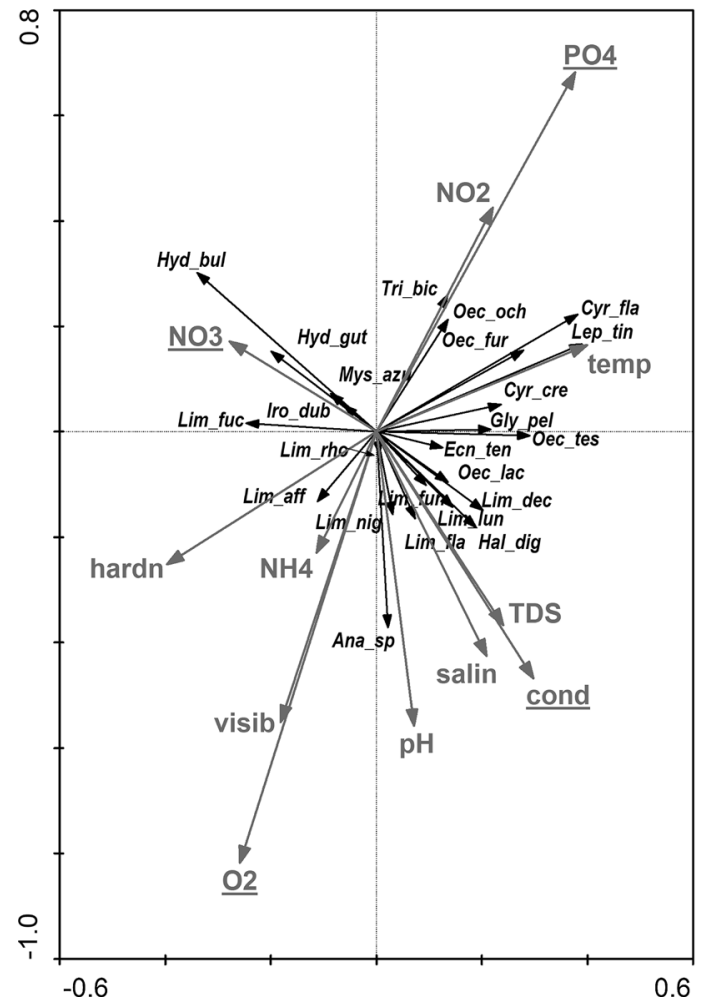

Fig. 6 RDA biplots showing caddisfly taxa in relation to physical and chemical a and structural $\mathbf{b}$ parameters of the River Oder (the underlined variables are significant). The

transformed: as a result, the number of microhabitats increased, thereby enhancing the river's habitat heterogeneity. This, in turn, led to a rise in the numbers of taxa, varied assemblages, greater biodiversity and a diverse structure of functional groups among caddisflies. Moreover, the stretch of the Oder with its groynes that we studied is evidently associated with the oxbows, thereby relating to natural rivers. This may indicate that groynes promote a caddisfly fauna typical of natural or restored watercourses. After nearly 300 years since the groynes were constructed, habitats with characteristic features have formed and stabilised in the river, which to a large extent may perform similar functions to the natural habitats formerly more prevalent in these systems. Groynes may replicate habitats historically created by fallen trees, and in this light they can be regarded as a replacement for large tree trunks and woody debris in an unmodified river system. In parallel, groynes and groyne fields can be compared to watercourses in (b)

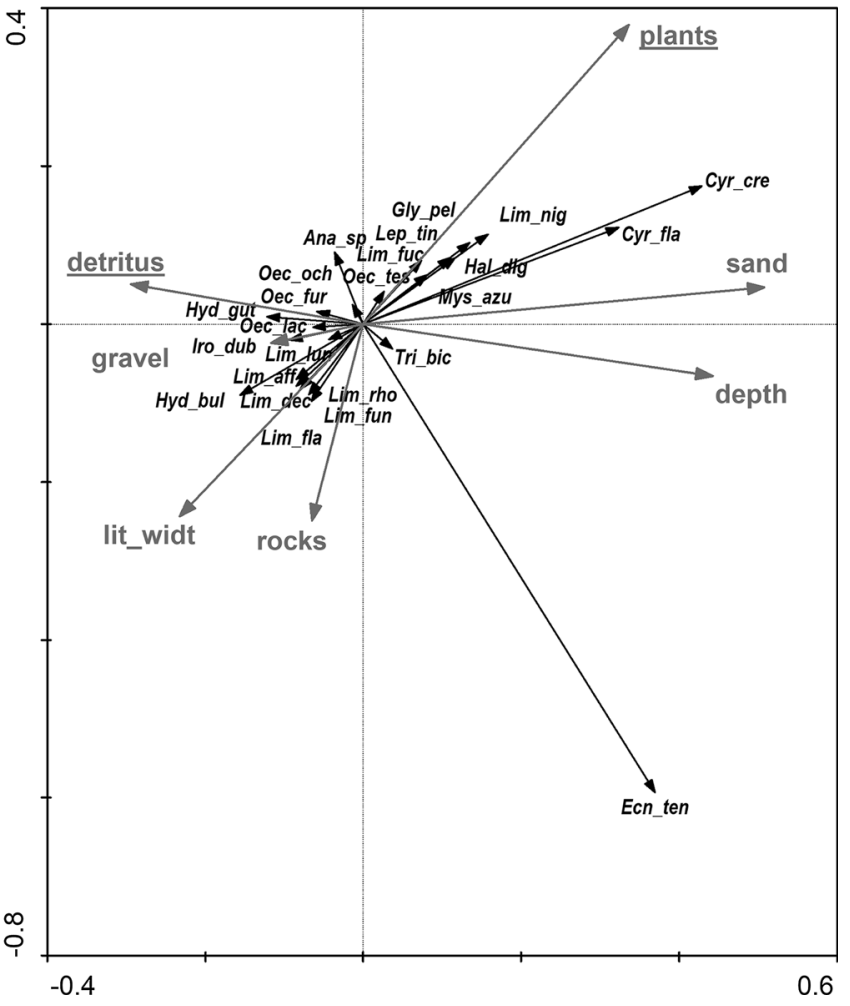

abbreviations of the variables and caddisfly taxa codes are given in Tables 1 and 2, respectively

which there is a naturally occurring, distinct pool-riffle sequence, clearly favouring a high level of diversity among the Trichoptera (Schmera \& Eros, 2004; Feio et al., 2005). The presence of groynes increased taxon richness almost threefold and species diversity twofold in relation to the control sites. Moreover, the species composition has been enriched primarily by species from the families Limnephilidae and Leptoceridae, typical of standing waters, associated chiefly with tall reedbeds, nympheids and elodeids (Wallace, 1991). Large rivers generally have a species-rich trichopteran fauna (van Urk et al., 1991), whereas potamal zones are inhabited by certain species only. The species richness and composition of larval Trichoptera in the Oder is much the same as and typical of analogous stretches of other European rivers (van Urk et al., 1991; Uherkovich \& Nógrádi, 1995; Tockner et al., 2009). In the Oder, these factors are evidently governed by the presence of groynes: without them, the river's fauna would be considerably 
Fig. 7 Two-dimensional non-metric multidimensional scaling (NMDS) of rivers (Oder nowadays and in the past, Bug, Neman, and Elbe), oxbows (in the Oder and Bug valleys) and a canal (Oder-Spree) based on caddisfly taxa composition (the presence-the absence data)

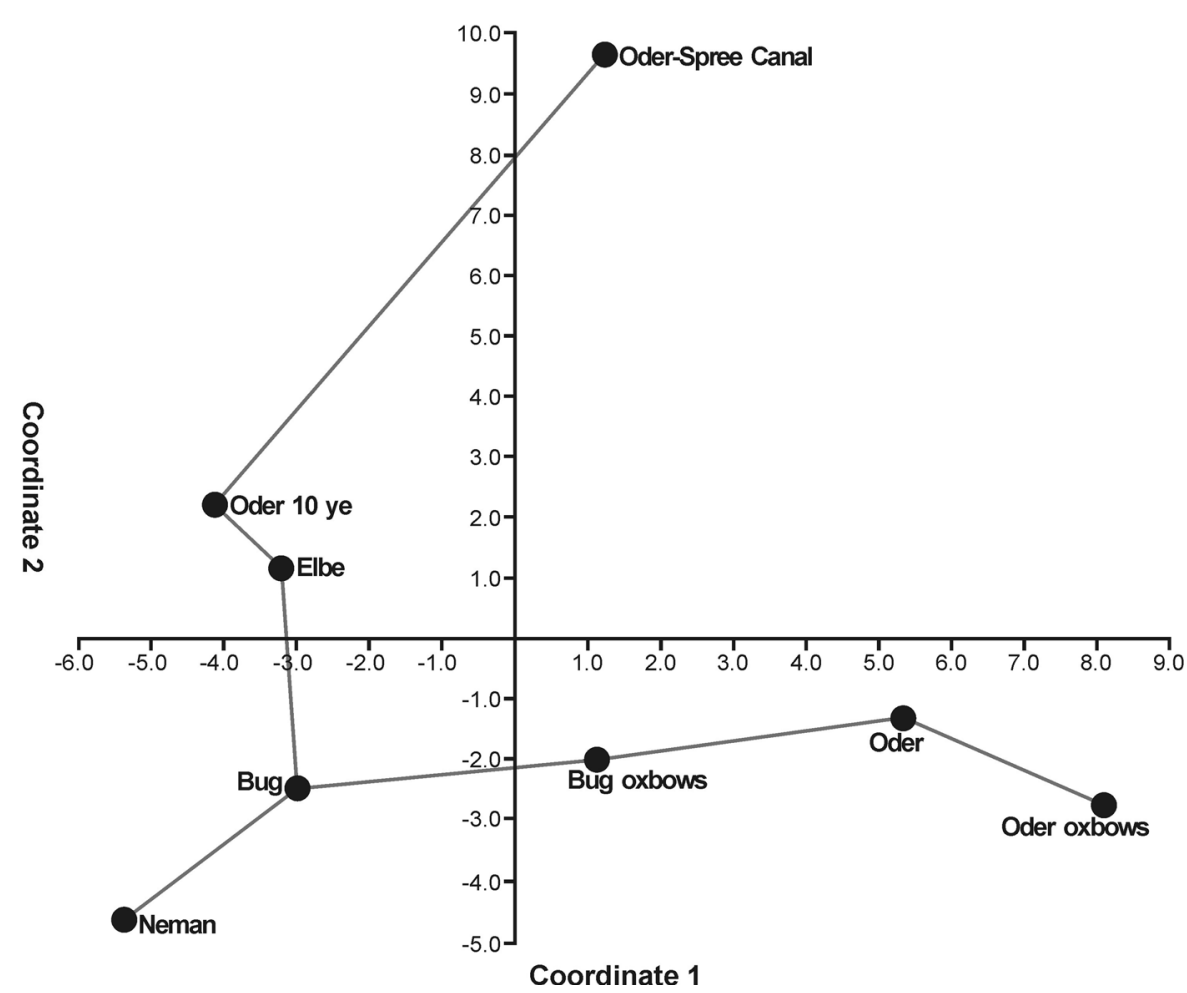

poorer. All of the above confirms our second hypothesis that groynes may support secondarily the caddisfly biodiversity of the river and its valley. In natural riverine ecosystems, the assemblages we regard as being typical of groyne fields occur in lentic habitats, which are governed, for example, by the meandering of the river. This is confirmed by the results of Nakano and Nakamura (2006), who found a similar species composition of invertebrates in a restored meander and groyne stretch of the River Shibetsu. Again, the groyne tips provide suitable habitats for rheophils (Hydropsychidae), which occurred in small numbers or not at all at the control sites. This means that not only groyne fields but also current sites support different specialised fauna, which confirms our first and second hypotheses. In spite of factors unfavourable to invertebrates, both natural (e.g. variations in water level, flooding) and anthropogenic (e.g. pollution, water traffic), a specialised and quite stable assemblage of Trichoptera has developed along this stretch of the Oder. This is particularly evident in the groyne fields which act on the "inner island" principle, the taxonomic and functional distinctiveness of which are underscored by our results. According to Kimura et al. (2011), the number of caddisfly species and diversity index before and after the flood on the River Shinano were relatively constant, which indicates that these insects are well adapted, at least in relation to natural disturbances. Consequently, they are good indicators of the various transformations of riverine environments and are useful for the possible monitoring of renaturalisation processes.

The colonisation of a river valley by invertebrates can take place over various distances, and its success depends on the dispersal abilities of particular species, the availability of suitable habitats (microhabitats) and the existence of source populations (e.g. Sundermann et al., 2011; Müller-Peddinghaus \& Hering, 2013). Important habitats enhancing river populations in river valleys are the various types of waters, including oxbows (Ward et al., 2002), which are regarded as biodiversity "hot spots" (Simon et al., 2013). In the Danube riverscape, for example, dynamically connected water bodies (channels) were found to be crucial for maintaining the biodiversity of dragonflies (Tockner et al., 1999). The occurrence of particular caddisfly species in the Oder groyne fields is to a large extent due to the presence of standing water bodies (oxbows) nearby. Evidence for this may be the high 
degree of qualitative similarity (46.5\%) between the stretch with groynes and the oxbows; for comparison, the same index for the control sites and oxbows is $26 \%$. The significant relationships between the faunas of the groyne fields and oxbows were also indicated by the NMDS plot as well as the clear distinction of stagnophilous assemblages 1 and 3, which supports the first hypothesis of our study. Apart from spatial proximity, the dispersal abilities of some species, especially males (Winterbourn et al., 2007), and upstream/downstream colonisation probably contribute to a high similarity index. The potential effects of temporary water bodies in a river valley are rather small, as they support a specific assemblage of caddisflies with different habitat preferences (Wallace, 1991). According to Sundermann et al. (2011), an appropriate species pool in the close vicinity of a river is one of the more important preconditions of successful recolonisation and river restoration. The numerous oxbows in the Oder valley offer a positive recolonisation potential for the river. Their presence and short distance from the mainstream will have shaped the fauna of groyne fields both in the past and at present. For a river, oxbows are a refuge of many species, which, as a result of natural or human-induced disasters or hydro-engineering measures, for example, may have been eliminated from the mainstream. Dispersal of caddisfly species occurs in both the larval and imaginal stages and, moreover, operates in both directions, i.e. from river to oxbow and vice versa. The families Polycentropodidae and Leptoceridae are dominant among the species common to both habitats: this may testify to their greater mobility and eurytopicity. On the other hand, the distinctness of oxbows is ensured by a large group of Limnephilidae species, which have more specialised habitat requirements. This would confirm the hypothesis of Müller-Peddinghaus \& Hering (2013), according to which habitat specialists among caddisflies are generally weaker dispersers. The biodiversity indices of both the river section with groynes and oxbows are quite high (2.62 and 2.26, respectively) in relation to the control sites. The complex dispersal processes among them and the occurrence of as many as 11 taxa exclusive to the groyne stretch will tend to increase the biodiversity of the whole valley. The diverse species pool in the surroundings will increase the probability of successful recolonisation (Robinson et al., 2002; Sundermann et al., 2011), a finding that stands in agreement with our own results.

Functional groups of caddisflies in the context of the groyne system

Flow dynamics and river stability are generally regarded as the main factors affecting the distribution of invertebrates in rivers (Jowett, 2003; Wang et al., 2014). Our observations showed that the occurrence pattern of functional caddisfly groups based on river current preferences is typical and expected: dynamic eddy shading by groyne tips (Yossef, 2005) is tolerated by only a few rheophilic species, but the groyne fields, where the current is weaker, are preferred by limnobionts and limnophils. Similar patterns obtained for groyne fields and oxbows also confirm our first hypothesis: not only species composition but also functional groups reflect close relations between these habitat types. At groyne tips the fauna is more exposed to hydraulic stress in large rivers because of shipping, a fact emphasised by Brunke et al. (2002) in the middle Elbe. Fish are a further factor limiting species richness at current sites in the Oder: Bischoff \& Wolter (2001) showed that young rheophilic fish were dominant at groyne tips in comparison to other riverine habitats and that they were responsible for the significant predatory pressure on insect larvae. The stability of a river is governed not only by flow dynamics but also by the type of substrate, sediment transport and, as mentioned earlier, aquatic and riparian vegetation (Rosgen, 1996). All these factors in combination make for a better species richness and higher mean densities in groyne fields than in the deeper parts (groyne tips) of the river. This corresponds with the results of the studies on invertebrates in the River Shibetsu with groynes (Nakano \& Nakamura, 2006). All the above factors, and especially the vegetation and shading, also govern the trophic structure of invertebrates in a watercourse (Warner \& Hendrix, 1984), although in the case of large rivers, their importance is regarded as marginal because of the large volumes of water involved. If, however, we bear in mind that caddisflies are limited to riparian zones, these factors are of significance within groyne fields, as our results have indicated.

Groyne construction has altered the trophic structure of caddisflies: it has become more diversified, even with respect to the proportions of the various 
trophic categories, especially with reference to the control sites. For comparison, Scholz et al. (2005) also found six functional groups (FG) among the caddisflies of the middle Elbe, the dominant ones being filter feeders and predators. In the Oder, we found filter feeder-predators to be the most numerous at the currents sites, while shredder-predators were the most numerous at the control sites and in the groyne fields. The presence of numerous filter feeders may be beneficial as regards improving water quality in a river such as the Oder: this was noted by Wetzel et al. (2014), who studied estuarine ecosystems with groynes in Germany. Among all riverine habitats, the trophic structure of the groyne fields was the most diversified and similar to the structure of the oxbows. In this case, too, our first hypothesis has been confirmed. Shredder-predators, consisting mainly of large Limnephilidae, depend on the availability of detritus (Wiggins, 2004) in groyne fields, which is derived mainly from the riparian zones, since the arboreal vegetation here is rather sparse. According to Gregory et al. (1991), riparian plant communities offer an abundant and diverse food base for aquatic invertebrates: caddisflies take advantage of this, and groyne fields are colonised by shredder-predator species (assemblage 1). Van den Brink et al. (1996), who investigated the lower Rhine and Meuse floodplains, also found that vegetation was crucial for shredders and predators. According to Rawer-Jost et al. (2000), shredders and predators are good indicators as regards the detection of disturbances (pollution) in running waters. The distribution of the large group of Limnephilidae was governed by TDS and conductivity, which may signify this type of dependence. Classifications based on trophic groups are useful for studies of food dynamics, trophic relationships and the evolution of system complexity in changing environmental conditions (Gérino et al., 2003), but the response of organisms from different categories is not always unequivocal.

Factors influencing Trichoptera in a large river

Although the physical and chemical together with structural parameters explained the variability of Trichoptera in the Oder's riverine habitats to only a minimal extent, their significance in particular cases was comparable, which confirmed our third research hypothesis. As we anticipated, both groups of factors, to a large extent modified by human agencies, will be important to this sensitive group of insects. The fact that most of the RDA variability (ca 76\%) remains unexplained is quite a common situation in many similar studies of macroinvertebrates: this is probably a consequence of the natural complexity and variability of watercourses (Feio et al., 2005; Ruiz-García et al., 2012). For Trichoptera, the significant structural factors turned out to be the vegetation coverage at particular sites and a substrate with detritus. SzlauerŁukaszewska (2015) obtained similar results in the same river for ostracods. Buczyński et al. (2017) also found that the vegetation coverage factor was significant for the distribution of dragonflies at the same sites studied along the Oder. For Trichoptera, both factors are important in the context of food resources, foraging areas, case/net attachment, pupation and protection from predators. Where groynes have been constructed, the groyne fields favour plant development and detritus deposition. In addition, the presence of groynes in these places stabilises the river, controls the adsorption of nutrients and shading, which in turn regulates the water temperature in the littoral zone (Wang et al., 2014). This again creates favourable conditions for the functioning of many river vertebrates and invertebrates. That is why the restoration of aquatic vegetation in degraded rivers is key to their renaturalisation (Coops et al., 2006; Tockner et al., 2009); groynes of the type studied here assist this process.

Groyne fields thus govern the occurrence of Trichoptera taxa with definite preferences for plants and detritus: both RDA and cluster analysis demonstrated this. At the same time, at the sample level, the Mann-Whitney U-test showed there to be no significant differences between sites with or without plants as regards densities and taxa richness. The same results applied to these two indices on the four types of substrate: the Kruskal-Wallis tests did not reveal any differences. In contrast, the total number of taxa in such comparisons is a sensitive metric: there were four species at only the control sites without plants, but twice as many at such sites with plants. At sites with a detritus substrate this index was the highest compared with the other types - as many as 26 taxa were found there (Table 3). Many studies acknowledge that the presence of vegetation and detritus increases the species richness of aquatic invertebrates (e.g. Müller, 2002; Schneider \& Winemiller, 2008). It is worth 
Table 3 Metrics of the trichopteran fauna of different types of substrate in the River Oder and its oxbows (m_N_t-mean taxa number, m_den-mean density, t_N_t—total number of taxa,

\begin{tabular}{|c|c|c|c|c|c|c|c|}
\hline & Substratum & m_N_t & m_den & $\mathrm{t} \_\mathrm{N} \_\mathrm{t}$ & t_N_i & $\mathrm{H}$ & $\mathrm{E}$ \\
\hline \multirow[t]{4}{*}{ River } & Detritus on mud & 2.72 & 9.95 & 26 & 204 & 2.15 & 0.33 \\
\hline & Sand & 2.53 & 9.37 & 24 & 177 & 2.58 & 0.55 \\
\hline & Gravel & 3.38 & 15.46 & 10 & 54 & 1.80 & 0.61 \\
\hline & Rocks & 2.11 & 5.63 & 16 & 74 & 2.14 & 0.53 \\
\hline \multirow[t]{4}{*}{ Oxbows } & Detritus on mud & 3.95 & 13.73 & 28 & 328 & 2.27 & 0.35 \\
\hline & Sand & 3.59 & 8.85 & 23 & 183 & 2.24 & 0.41 \\
\hline & Gravel & 1.57 & 3.24 & 6 & 11 & 1.64 & 0.86 \\
\hline & Rocks & 1 & 3 & 2 & 2 & 0.69 & 1.00 \\
\hline
\end{tabular}

The highest scores are shown in bold

emphasising the fact that the highest mean densities and number of taxa in the Oder were recorded on a gravel substrate (Table 3), which at the same time supported the taxonomically poorest fauna, dominated by Anabolia sp. and Hydropsyche bulgaromanorum Malicky, 1977. Such ambiguous results (Table 3) may be evidence for the disturbing influence of other factors at particular sites. Generally speaking, caddisflies in riverine ecosystems prefer hard (solid) substrata (Pliūraitė \& Kesminas, 2004; Graf et al., 2016). In human-disturbed watercourses, certain distribution patterns can be modified: e.g. Jähnig \& Lorenz (2008), in their studies on macroinvertebrates in restored steams, also found CPOM and coarse gravel important for high taxa numbers and abundances. Similarly, Verdonschot et al. (2016) found cobbles, sand cover and CPOM (Coarse Particulate Organic Matter) related to higher EPT richness and diversity in restored and degraded river sections. Our results show that gravel is important for taxa representing different functional groups.

Like most other large rivers, the Oder is exposed to contamination as a result of urbanisation as well as industrial and agricultural practices (Coops et al., 2006). Even though the general state of its waters is described as poor (Lewicki, 2011; WIOŚ Wrocław, 2012), the mean values of the physical and chemical parameters that we obtained do not deviate significantly from those measured in other large European rivers (Tockner et al., 2009). Indeed, the factors crucial to the occurrence of caddisflies, like oxygen, nitrate and phosphate, which are intimately related to
t_N_i-total number of individuals, $\mathrm{H}$-Shannon's diversity index, E-evenness) 
waters are crucial to their occurrence, these insects (or at least certain species) can serve as indicators of eutrophication processes in large rivers.

Acknowledgments We would like to thank the five anonymous reviewers for their valuable comments and suggestions which helped us to improve the manuscript. The research was financed under grant No. N 304327236 received from the Polish Ministry of Science and Higher Education.

Open Access This article is distributed under the terms of the Creative Commons Attribution 4.0 International License (http:// creativecommons.org/licenses/by/4.0/), which permits unrestricted use, distribution, and reproduction in any medium, provided you give appropriate credit to the original author(s) and the source, provide a link to the Creative Commons license, and indicate if changes were made.

\section{References}

Barbosa, A. E., E. Alves, R. M. V. Cortes, P. M. Silva-Santos, F. Aguiar \& T. Ferreira, 2006. Evaluation of environmental impacts resulting from river regulation works. A case study from Portugal. In Ferreira, T., E. C. T. L. Alves, J. G. A. B. Leal \& A. H. Cardoso (eds), Proceedings of the International Conference on Fluvial Hydraulics, Lisbon, Portugal, 608 September 2006. River Flow 2006, vol. 2. Taylor \& Francis, London: 2081-2092.

Bischoff, A. \& C. Wolter, 2001. Groyne-heads as potential summer habitats for juvenile rheophilic fishes in the Lower Oder, Germany. Limnologica 32: 17-26.

Boyero, L., 2003. The quantification of local substrate heterogeneity in streams and its significance for macroinvertebrate assemblages. Hydrobiologia 499: 161-168.

Brunke, M., A. Sukhodolov, H. Fischer, S. Wilczek, C. Engelhardt \& M. Pusch, 2002. Benthic and hyporheic habitats of a large lowland river (Elbe, Germany): influence of river engineering. Internationale Vereinigung für Theoretische und Angewandte Limnologie Verhandlungen 28: 153-156.

Buczyński, P., A. Szlauer-Łukaszewska, G. Tończyk \& E. Buczyńska, 2017. Groynes: a factor modifying the occurrence of dragonfly larvae (Odonata) on a large lowland river. Marine and Freshwater Research 68: 1653-1663.

Cèrèghino, R., J. L. Giraudel \& A. Compin, 2001. Spatial analysis of stream invertebrates distribution in the AdourGaronne drainage basin (France), using Kohonen self-organizing maps. Ecological Modelling 146: 167-180.

Coops, H., K. Tockner, C. Amoros, T. Hein \& G. Quinn, 2006. Restoring lateral connections between rivers and floodplains: lessons from rehabilitation projects. In Verhoeven, J. T. A., B. Beltman, R. Bobbink \& D. F. Whigham (eds), Ecological Studies, Vol. 190., Wetlands and natural resource management Springer, Berlin: 15-32.

Czachorowski, S., 2004. The last natural river of eastern Europe? Caddisflies (Trichoptera) of the Neman River. Latvijas Entomologs 41: 44-51.
Czachorowski, S. \& E. Serafin, 2004. The distribution and ecology of Hydropsyche bulgaromanorum and Hydropsyche contubernalis (Trichoptera: Hydropsychidae) in Poland and Belarus. Lauterbornia 50: 85-98.

Feio, M. J., R. Vieira-Lanero \& M. A. Graça, 2005. Do different sites in the same river have similar Trichoptera assemblages? Limnetica 24: 251-261.

Gérino, M., G. Stora, F. François-Carcaillet, F. Gilbert, J. C. Poggiale, F. Mermillod-Blondin, G. Desrosiers \& P. Vervier, 2003. Macro-invertebrate functional groups in freshwater and marine sediments: a common mechanistic classification. Vie et Milieu 53: 221-231.

Gordon, N. D., T. A. McMahon \& B. L. Finlayson, 1992. Stream hydrology: An introduction for ecologists. Wiley, Chichester.

Graf, W., J. Murphy, J. Dahl, C. Zamora-Muñoz \& M. J. LópezRodríguez, 2008. Distribution and Ecological Preferences of European Freshwater Organisms, Vol. 1. Trichoptera, Pensoft.

Graf, W., P. Leitner, I. Hanetseder, L. D. Ittner, F. Dossi \& C. Hauer, 2016. Ecological degradation of a meandering river by local channelization effects: a case study in an Austrian lowland river. Hydrobiologia 772: 145-160.

Gregory, S. V., F. J. Swanson, W. A. McKee \& K. W. Cummins, 1991. An ecosystem perspective of riparian zones: focus on links between land and water. Bioscience 41: 540-551.

Hammer, ̌̌., D. A. T. Harper \& P. D. Ryan, 2001. PAST: paleontological statistics software package for education and data analysis. Palaeontologia Electronica 4: 1-9.

Holzenthal, R. W., R. J. Blahnik, A. L. Prather \& K. M. Kjer, 2007. Order Trichoptera Kirby, 1813 (Insecta), Caddisflies. Zootaxa 1668: 639-698.

Horsák, M., J. Bojková, S. Zahrádková, M. Omesová \& J. Helešic, 2009. Impact of reservoirs and channelization on lowland river macroinvertebrates: a case study from Central Europe. Limnologica 39: 140-151.

Jähnig, S. C. \& A. W. Lorenz, 2008. Substrate-specific macroinvertebrate diversity patterns following stream restoration. Aquatic Sciences 70: 292-303.

Jowett, I. G., 2003. Hydraulic constraints on habitat suitability for benthic invertebrates in gravel-bed rivers. River Research and Applications 19: 495-507.

Kimura, G., E. Inoue \& K. Hirabayashi, 2011. The effect of a summer flood on the density of caddisfly (Trichoptera) in the middle reaches of the Shinano River, Japan. Zoosymposia 244: 235-243.

Lewicki, Z. (ed.), 2011. Stan środowiska w województwie lubuskim w latach 2009-2010. Biblioteka Monitoringu Środowiska, Zielona Góra.

Malmqvist, B. \& S. Rundle, 2002. Threats to the running water ecosystems of the world. Environmental Conservation 29: 134-153.

Mazão, G. R. \& P. da Conceição Bispo, 2016. The influence of physical instream spatial variability on Chironomidae (Diptera) assemblages in Neotropical streams. Limnologica-Ecology and Management of Inland Waters 60: 1-5.

Müller, O., 2002. Die Habitate von Libellenlarven in der Oder (Insecta, Odonata). Naturschutz und Landschaftspflege in Brandenburg 11: 205-212.

Müller, R., L. Hendrich, M. Klima \& J. H. E. Koop, 2006. Das Makrozoobenthos des Oder-Spree-Kanals und der 
Fürstenwalder Spree in Brandenburg. Lauterbornia 56: 141-154.

Müller-Peddinghaus, E. \& D. Hering, 2013. The wing morphology of limnephilid caddisflies in relation to their habitat preferences. Freshwater Biology 58: 1138-1148.

Nakano, D. \& F. Nakamura, 2006. Responses of macroinvertebrate communities to river restoration in a channelized segment of the Shibetsu River, Northern Japan. River Research and Applications 22: 681-689.

Pirvu, M. \& O. Pacioglu, 2012. The ecological requirements of caddisflies larvae (Insecta: Trichoptera) and their usefulness in water quality assessment of a river in south-west Romania. Knowledge and Management of Aquatic Ecosystems 407: 03.

Pliūraite, V. \& V. Kesminas, 2004. Species composition of macroinvertebrates in medium-sized Lithuanian rivers. Acta Zoologica Lituanica 14: 10-25.

Rast, G., P. Obrdlik \& P. Nieznański (eds), 2000. Atlas niv Odry, Atlas obszarów zalewowych Odry, Oder-Auen-Atlas. WWF-Auen-Institut, Rastatt.

Rawer-Jost, C., J. Böhmer, J. Blank \& H. Rahmann, 2000. Macroinvertebrate functional feeding group methods in ecological assessment. Hydrobiologia 422: 225-232.

Robinson, C. T., K. Tockner \& J. V. Ward, 2002. The fauna of dynamic riverine landscapes. Freshwater Biology 47: 661-677.

Rosgen, D. L., 1996. Applied River Morphology. Wildland Hydrology Books, Pagosa Springs.

Rozporządzenie Ministra Środowiska z dnia 22 października 2014 r. w sprawie sposobu klasyfikacji jednolitych części wód powierzchniowych oraz środowiskowych norm jakości dla substancji priorytetowych (Dz.U. 2014 poz. 1482).

Ruiz-García, A., J. Márquez-Rodríguez \& M. Ferreras-Romero, 2012. Implications of anthropogenic disturbance factors on the Trichoptera assemblage in a Mediterranean fluvial system: are Trichoptera useful for identifying land-use alterations? Ecological Indicators 14: 114-123.

Schmera, D. \& T. Eros, 2004. Effect of riverbed morphology, stream order and season on the structural and functional attributes of caddisfly assemblages (Insecta: Trichoptera). Annales de Limnologie 40: 193-200.

Schneider, K. N. \& K. O. Winemiller, 2008. Structural complexity of woody debris patches influences fish and macroinvertebrate species richness in a temperate floodplain-river system. Hydrobiologia 610: 235-244.

Schöll, F., J. Błachuta \& P. Soldán, 2003. Makrozoobentos Odry 1998-2001. Międzynarodowa Komisja Ochrony Odry przed Zanieczyszczeniem, Wrocław.

Scholz, M., S. Stab, F. Dziock \& K. Henle, 2005. Konzepte für die Nachhaltige Entwicklung Einer Flusslandschaft, Vol. 4. Weißensee Verlag, Berlin, Lebensräume der Elbe und ihrer Auen.

Serafin, E., 2004. Species diversity of the caddisflies (Trichoptera) in the left-bank River Bug valley. Teka Komisji Ochrony Kształtowania Środowiska Przyrodniczego 1: 195-201.

Simon, A., Bennett, S. J. \& J. M. Castro (eds), 2013. Stream restoration in dynamic fluvial systems: scientific approaches, analyses, and tools. Vol. 194. Wiley, Hoboken.
Sundermann, A., S. Stoll \& P. Haase, 2011. River restoration success depends on the species pool of the immediate surroundings. Ecological Applications 21: 1962-1971.

Szlauer-Łukaszewska, A., 2014. The dynamics of seasonal ostracod density in groyne fields of the Oder River (Poland). Journal of Limnology 73: 298-311.

Szlauer-Łukaszewska, A., 2015. Substrate type as a factor affecting the ostracod assemblages in groyne fields of the Oder River (Poland). North-Western Journal of Zoology 11: 274-287.

ter Braak, C. J. F. \& P. Šmilauer, 2002. CANOCO Reference Manual and CanoDraw for Windows User's Guide Version 4.5. Biometris-Plant Research International, Wageningen České Budějovice.

Tockner, K., F. Schiemer, C. Baumgartner, G. Kum, E. Weigand, I. Zweimüller \& J. B. Ward, 1999. The Danube restoration project: species diversity patterns across connectivity gradients in the floodplain system. Regulated Rivers: Research \& Management 15: 245-258.

Tockner, K., C. T. Robinson \& U. Uehlinger (eds), 2009. Rivers of Europe. Academic Press, Amsterdam.

Uherkovich, Á. \& S. Nógrádi, 1995. Studies on caddisfly (Trichoptera) communities of larger rivers in Hungary. In Holzenthal, R. W. \& O. S. Flint, Jr. (eds), Proceedings of the 8th International Symposium on Trichoptera, Minneapolis and Lake Itasca, Minnesota, 9-15 July 1995. Ohio Biological Survey, Columbus, Ohio: 459-465.

Van den Brink, F. W. B., G. van der Velde, A. D. Buijse \& A. G. Klink, 1996. Biodiversity in the lower Rhine and Meuse river-floodplains: its significance for ecological river management. Netherland Journal of Aquatic Ecology 30: 129-149.

Van Urk, G., F. C. M. Kerkum \& A. Bij de Vaate, 1991. Caddis flies of the Lower Rhine. In Tomaszewski, C. (ed.), Proceedings of the 6th International Symposium on Trichoptera, Łodź-Zakopane (Poland), 12-16 September 1989. Adam Mickiewicz University Press, Poznań: 89-94.

Verdonschot, R. C., J. Kail, B. G. McKie \& P. F. Verdonschot, 2016. The role of benthic microhabitats in determining the effects of hydromorphological river restoration on macroinvertebrates. Hydrobiologia 769: 55-66.

Wallace, I. D., 1991. Research and survey in nature conservation No. 32. A review of the Trichoptera of Great Britain. Nature Conservancy Council, Northminster House, Peterborough.

Wang, Z. Y., J. H. Lee \& C. S. Melching, 2014. River dynamics and integrated river management. Tsingua Universite Press, Beijing, and Springer-Verlag, Berlin.

Ward, J. V., K. Tockner, D. B. Arscott \& C. Claret, 2002. Riverine landscape diversity. Freshwater Biology 47: 517-539.

Warner, R. E. \& K. M. Hendrix, 1984. California Riparian Systems: Ecology, Conservation, and Productive Management. University of California Press, Berkeley.

Wetzel, M. A., J. Scholle \& K. Teschke, 2014. Artificial structures in sediment-dominated estuaries and their possible influences on the ecosystem. Marine Environmental Research 99: 125-135.

Wiggins, G. B., 2004. Caddisflies: the underwater architects. University of Toronto Press, Toronto. 
Winterbourn, M. J., W. L. Chadderton, S. A. Entrekin, J. L. Tank \& J. S. Harding, 2007. Distribution and dispersal of adult stream insects in a heterogeneous montane environment. Fundamental and Applied Limnology 168: 127-135.

Wrocław, W. I. O. Ś., 2012. Raport o Stanie Środowiska w Województwie Dolnośląskim w 2011 Roku. Biblioteka Monitoringu Środowiska, Wrocław.
Yossef, M. F. M., 2005. Morphodynamics of Rivers with Groynes. Delft University Press, Delft.

Żelazo, J. \& Z. Popek, 2002. Podstawy Renaturyzacji Rzek. Wydawnictwo Szkoły Głównej Gospodarstwa Wiejskiego, Warszawa. 